\title{
Impact of MNP on Consumer Behaviour With Reference To Tirupati City Of Andhra Pradesh
}

\author{
Dr. M. Reddi Naik \\ Assistant Professor of Commerce, Govt. Degree and PG College, Puttur Chittoor District, Andhra Pradesh
}

\begin{abstract}
The telecom industry is one of the fastest growing industries in India. By the end of July 2014 the total wireless subscribers has reached to more than 918 millions so there is an urgent need to provide more services to them. Mobile Number Portability (MNP) helps phone users to change from one mobile operator to another without changing mobile number. It encourages market competition level and ensures better service. This paper examine consumer awareness and preference about mobile number portability and trais to find out the factors which motive user to opting MNP. The research deign used in this study is of descriptive nature. For primary data collection were random sampling method was adopted and distributed of questionnaire to the users. The data were collected from 259 mobile users from different service operators and collecting of the customer opinion survey was taken among the selected users. The collected data included personal detail, existing operator, MNP awareness motivated factors to choose operator etc., the data were analysed by percentage, chi-square test was applied. The secondary data were collected from available literature sources. The finding of the study, most of the user having awareness about MNP and many factors are influenced to user towards opting MNP and same time it is an evidence that about 13 percent of subscribers are making MNP request by the end of July 2014. It is evidence that most of the users are unhappy with current operator. The same outcome is exposed in this study.
\end{abstract}

Key words: mobile number portability, consumer behavior, TRAI, motivation, porting

\section{Introduction}

Since liberalization in 1991, telecom sector in India has registered an unparalleled development. Currently it is valued at $\$ 130 \mathrm{bn}$ contributing significantly to the GDP of India. In terms of international market, India is world's second largest wireless market after China. According to reports by TRAI (Telecom regulatory authority India), by the end of June 2014, the total wireless subscribers has reached to more than 918 million and registered a monthly growth of 0.42 wireless subscriber in India. Wireless subscriber in rural area is 378.29 million and urban is 540.44. It encourages market competition level and ensures better service in India. The operators have developed alternatives strategies to retain their loyal customers. The Indian telecom industry is one of the fastest growing in the world.

Market shares of different operators in India:

There are big players in Telecom sector in India namely Bharathi Airtel, Vodafone, Idea cellular, Reliance, Aircel, TATA, Uninor and Government player like BSNL, MTNL. The wireless service providers market shares as per July 2014 is shown in following pie-chart.

Service provider wise market share as on July 2014

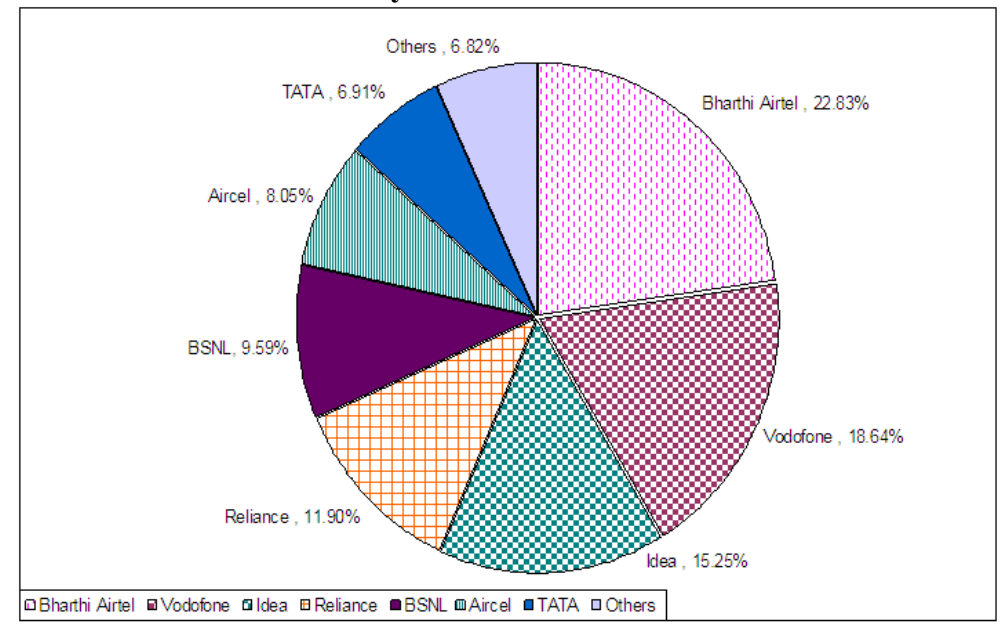

Source: TRAI 


\section{The history of MNP}

The world's first country to introduce Mobile Number Portability (MNP) was Singapore in 1997, followed by the UK, Hong Kong and the Netherlands in 1999. As of 2003, a number of other countries, especially in Europe require MNP. In India, MNP was implemented in a phased manner, and the first phase was to start in Metro cities and a circle by December 31, 2009, and the second phase, in the rest of the country by March 2010. The Government later decided to implement it in the entire country in one go by March 31, 2010. The launch of Mobile Portability Services was again extended to June 30, 2010, due to a lack of readiness of various stake holders. It was firstly introduced in HARYANA after awaiting service in India, in Nov 2010 and on 20 January 11 it was introduced a across India.

\section{How to change mobile operator}

Earlier the subscribers were hesitant to change their operators due to fear of losing their existing mobile number, but now with the introduction of MNP subscribers can easily switch to new operator while retaining the same mobile number. But users cannot switch operator and retain number if they have been with that operator for less than three months. The Prepaid users have to lose their balance talk time if they switch to a different operator. The maximum downtime between deactivating the existing connection and starting the new connection will be of two hours. TRAI has forwarded the responsibility to the Department of Telecommunications (DoT) to select an operator who will be licensed to manage an end-to-end MNP solution.

$>$ Subscribers must pay up all pending bills before making an application for MNP.

$>$ The porting fee is to be paid to the new operator.

$>$ No payment is required to be given to the operator when you are leaving.

$>$ According to TRAI the porting between mobile operators should be accomplished within four days.

\section{Impact on Service Providers}

$\checkmark$ Competition among service providers will increase but profit margins are likely to operators who have already a strong customer base will be able to retain their customers by providing competitive tariffs.

$\checkmark$ New service providers will find it easier to enter and survive in market by providing competitive rates and Value Added Services.

$\checkmark \quad$ Service providers will also be able retain customer loyalty and build higher company value.

$\checkmark \quad$ The service providers will have better control over the quality of routing.

\section{Impact on Subscribers}

$\checkmark$ Subscribers can now use one number throughout their life and have the flexibility of changing service providers if they are unhappy with the tariff, service, connectivity, etc.

$\checkmark$ Subscribers are more likely to get efficient services at lower rates.

$\checkmark$ A subscriber can make a porting request only after 90 days of activation of connection.

$\checkmark$ Subscribers can also change operators within their registered circles only.

\section{Present status of MNP}

At present wireless subscriber number has reached to more than 918 millions at the end of July 2014.regisred a monthly growth of 0.42 wireless subscribers in India .Among from rural area 378.29 million and urban 540.44 millions. Mobile number portability as on the data reported by the service providers by the end of June 2014 about 12.72 million subscribers have submitted their request to different service providers for porting their mobile number

\section{Evaluation of MNP}

\begin{tabular}{|l|c|l|c|}
\multicolumn{2}{|c|}{ Service area wise MNP status at the end of July 2014 } \\
\hline \multicolumn{1}{|c|}{ Zone 1 } & $\begin{array}{c}\text { Number of porting requests } \\
\text { as on June 2014 }\end{array}$ & $\begin{array}{c}\text { Zumber of porting requests } \\
\text { as on June 2014 }\end{array}$ \\
\hline Delhi & 4880879 & Andhra Pradesh & 11826424 \\
\hline Gujarat & 10688519 & Assam & 434685 \\
\hline Himachal Pradesh & 434721 & Bihar & 2935684 \\
\hline Haryana & 4748554 & Karnataka & 14341917 \\
\hline Jammu Kashmir & 26245 & Kerala & 4792263 \\
\hline Maharashtra & 9847578 & Kolkata & 2882396 \\
\hline Mumbai & 5769700 & Madhya Pradesh & 7226353 \\
\hline Punjab & 4385916 & North East & 223667 \\
\hline Rajasthan & 12684001 & Orissa & 2671570 \\
\hline Uttar Pradesh-East & 6789431 & Tamil nadu & 7633486 \\
\hline Uttar Pradesh-West & 6628998 & West Bengal & 4870292 \\
\hline Total & $66,884,542$ & Total & $59,838,737$ \\
\hline Total(Zone 1+2) & $\mathbf{1 2 6 , 7 2 3 , 2 7 9}$ \\
\hline
\end{tabular}

Source: TRAI 
The above Table shows that the number of subscribers submitted their request to service providers for porting their mobile number as per the data reported officially by the different service providers by the end of July 2014 about 126.72 millions. MNP request by user in Zone 1, among the circle Rajasthan led the pack with 12.37 million request have been received. It was followed by Gujarat 10.69 million and the total request of zone 1 about 66884542 millions. Where in MNP request Zone-II about 14.34 millions request have been received by Karnataka followed by Andhra Pradesh 11.83 mill and total request from zone-II about 59838733 million. All over India MNP request (included July 2014 additions 2856500), about 126723279 millions so it is necessary to understand characteristics and reason for customer opting MNP. This paper examines consumer awareness and preference about mobile number portability and tries to find out the factors that motive use to opting MNP.

\section{Review of Literature}

There have been few significant studies in the field of mobile number portability. Muraganadam (2013) has delved That MNP Creates Competition Over the Network Provider and this is an advantage to consumer. The main reason for choosing MNP is poor connectivity and Network Problem, The user is facing this kind of Problems frequently with the current operator. According to Rajesh (2013) MNP will facilitate the easy exist of unsatisfied users, this also means operator will have to put up more effort to provide better service to retain the customers, it means the complains will have to set up more mobile phone towers upgrade the requirement and provide instant rectification of problems. So, the subscribes are always able to get connected and operator must focus on innovative service, quality of service, voice quality and low call drops etc.

According to Partiksinh Sureshsinh Vaghela (2012), the total number of subscribers opting for mobile number portability (MNP) has risen to 59.31 million, with Karnataka receiving the maximum number of 7.2 million requests till the end of July, according to official data. MNP allows users to switch operators while retaining their mobile numbers. "By the end of July 2012, about 59.31 million subscribers have submitted their requests to different service providers for porting their mobile number," the Telecom Regulatory Authority of India (Trai) said in a statement. Karnataka was followed by Andhra Pradesh and Rajasthan where 5.7 million and 5.6 million subscribers opted for the service. So it is necessary to understand characteristics and reasons of customer for using mobile number portability. These papers examine the consumer awareness and preference about mobile number portability and try to find out factors that motivate use of MNP. Result suggest respondents are not only aware about the MNP but they also know the procedure of using MNP and network coverage, customer care, quality of service are the main factors to switch over another service provider. Mobile number Portability helps mobile phone subscribers to change from one mobile operator to another without changing mobile phone number (B.K. Suthar et al., 2012). It encourages market competition level and encourages better services. This study aims to investigate the effects of MNP on mobile phone users in Gujarat telecom circle by focusing mobile phone user's perception and their behavior related to MNP.

\section{Objective of the Study}

* To study the impact of MNP on service user

* To know the factors which motivate the user towards the MNP

* To study the effect of MNP on different service operators

\section{Hypotheses}

* There is no significant relationship between Gender of the sample respondent and their willingness to change current mobile service provider

* There is no significant difference between the income of the subscriber and user satisfaction of current service provider.

\section{Research methodology}

For the purpose of research 300 respondents were randomly chosen, that include all service users, and were given questionnaires to 280 respondents, out of which 21 were rejected due to incomplete response. Finally, 259 respondents were selected for the study, and data interpreted.

\section{Tools and data collection}

Collected data were prepared master table and then incorporated in to excel sheet and tested with suitable tools and techniques, after that the table was clearly interpreted.

\section{Limitation of the Study}

The study was carried out in Tirupati city of Andhra Pradesh. The findings of the research may not fully applicable and generalized to other circle of the country. Finally 259 respondents information used for analysis. The information about the respondents are provided in the following table. 
Table 1: Distribution of sample respondents of demographical factors

\begin{tabular}{|l|l|c|c|}
\hline \multirow{2}{*}{ Particulars } & \multicolumn{1}{|c|}{ Classification } & \multicolumn{1}{c|}{$\begin{array}{c}\text { Number of } \\
\text { Respondents }\end{array}$} & Percentage \\
\hline \multirow{2}{*}{ Gender } & Male & 185 & 71.4 \\
\cline { 2 - 4 } & Female & 74 & 28.6 \\
\hline \multirow{5}{*}{ Age } & Below 20 years & 56 & 21.6 \\
\cline { 2 - 4 } & $20-30$ years & 99 & 38.2 \\
\cline { 2 - 4 } & $30-40$ years & 73 & 28.2 \\
\cline { 2 - 4 } & 40 above & 31 & 12.0 \\
\hline \multirow{5}{*}{ Monthly Income } & Below 10,000 & 43 & 16.6 \\
\cline { 2 - 4 } & $10001-20000$ & 89 & 34.4 \\
\cline { 2 - 4 } & $20000-30000$ & 64 & 24.7 \\
\cline { 2 - 4 } & 30000 and above & 63 & 24.3 \\
\hline
\end{tabular}

Source: Primary data

The above table- 1 shows that the demographical factors of the sample respondents. Out of 259 sample respondents about 185 ( 71.4 per cent), male and 74 ( 28.6 per cent) female respondents. In the age group of the sample respondents about 56 (21.6 per cent) are below 20 years age group, 99 (38.2 per cent) respondents between 20-30 years age group and 73 (28.2 per cent) respondents between 30-40 years age group and remaining 31 (12.0 per cent) respondents above 40 years age group. The monthly income of sample respondents about 89 (34.3 per cent) sample respondents have income 10000-20000, it was followed by 64 (24.7 per cent) respondents have income between 20000-30000 and remaining 63 (24.3 per cent) sample respondents have income is 30000 and above.

Table: 2 Distribution of Sample Respondents of Source of information about MNP

\begin{tabular}{|l|c|c|}
\hline \multicolumn{1}{|c|}{ Source Information } & No. of Respondents & Percentage \\
\hline Friends & 72 & 27.80 \\
\hline Advertisements & 91 & 35.14 \\
\hline Internet & 57 & 22.01 \\
\hline Family Members & 39 & 15.06 \\
\hline & 259 & 100.00 \\
\hline
\end{tabular}

Source: Primary data.

The above table shows that 35 per cent of the respondents got information through advertisements followed by 27 per cent through friends, 22 per cent of the respondents are from internet, remaining 15 percent of respondents are from family members so the majority of the respondents got information of MNP from advertisements.

Table: 3 Distribution of Sample Respondents of Consent level towards the switch over through MNP

\begin{tabular}{|l|c|c|}
\hline \multicolumn{1}{|c|}{ Particulars } & No. of Respondents & Percentage \\
\hline Strongly Agree & 12 & 4.63 \\
\hline Strongly disagree & 58 & 22.39 \\
\hline Agree & 71 & 27.41 \\
\hline Disagree & 118 & 45.56 \\
\hline Total & $\mathbf{2 5 9}$ & $\mathbf{1 0 0 . 0 0}$ \\
\hline
\end{tabular}

Source: Primary data.

The above table shows that 45 per cent of the respondents disagree about the changing of the operator frequently, followed by 27 percent of the respondents agree, 22 percent of the respondent strongly disagree and only 4 per cent strongly agree towards the switch over the operator through MNP.

Table: 4 Distribution of Sample Respondents towards the satisfaction level of Current Service Provider

\begin{tabular}{|l|c|c|}
\hline Particulars & No. of Respondents & Percentage \\
\hline Highly Satisfied & 8 & 3.09 \\
\hline Satisfied & 14 & 5.41 \\
\hline Neutral & 57 & 22.01 \\
\hline Dissatisfied & 66 & 25.48 \\
\hline Highly dissatisfied & 114 & 44.02 \\
\hline Total & 259 & 100.00 \\
\hline
\end{tabular}

Source: primary data.

As for the above table regarding the satisfaction level towards the present service provider, that 44 per cent of the respondent are highly dissatisfied with the current service provider, followed by 25 per cent are dissatisfied, 22 per cent of the respondent are neutral, 5 per cent respondents are satisfied and only 3 per cent 
of the respondents are highly satisfied with the present service provider. The majority of the respondents are dissatisfied with the current operator.

Table: 5 Distribution Of Sample Respondents Of Reasons For Dissatisfactions

\begin{tabular}{|l|c|c|}
\hline \multicolumn{1}{|c|}{ Particulars } & No. of Respondents & Percentage \\
\hline Coverage Problems & 74 & 28.57 \\
\hline Tariff Problems & 52 & 20.08 \\
\hline Roaming Problems & 12 & 4.63 \\
\hline Call Drops & 32 & 12.36 \\
\hline Consumer Services Delay & 51 & 19.69 \\
\hline Other Reasons & 38 & 14.67 \\
\hline Total & $\mathbf{2 5 9}$ & $\mathbf{1 0 0 . 0 0}$ \\
\hline
\end{tabular}

Source: Primary data.

Table 5 shows that 29 per cent of the respondents are dissatisfied due to coverage problem followed by 20 percent of the respondent's reason of tariff problem, 20 per cent are of poor consumer service and 12 per cent are frequently call drops so these three things make the consumer to switch over the operator.

Table: 6 Distribution of Sample Respondents of Plunk towards Switch over

\begin{tabular}{|l|c|c|}
\hline \multicolumn{1}{|c|}{ Particulars } & No. of Respondents & Percentage \\
\hline Already Switch over & 89 & 34.36 \\
\hline Switch over in Future & 45 & 17.37 \\
\hline Same Network & 125 & 48.26 \\
\hline & 259 & 100.00 \\
\hline
\end{tabular}

Source: primary data.

The above table shows that 34 percent of the respondents are dissatisfied with their current network, and have switched over to other network. 17 per cent of the respondents would like to switch over to other network in future the remaining 48 per cent will retain in same network.

Table: 7 Distribution of Sample Respondents of Current Service providers of the Respondents

\begin{tabular}{|l|c|c|}
\hline \multicolumn{1}{|c|}{ Particulars } & No. of Respondents & Percentage \\
\hline Bharthi Airtel & 71 & 27.41 \\
\hline Vodofone & 65 & 25.10 \\
\hline Idea & 32 & 12.36 \\
\hline Reliance & 20 & 5.00 \\
\hline BSNL & 38 & 14.67 \\
\hline Aircel & 18 & 6.95 \\
\hline TATA & 11 & 4.25 \\
\hline Others & 4 & 4.27 \\
\hline Total & $\mathbf{2 5 9}$ & $\mathbf{1 0 0 . 0 0}$ \\
\hline
\end{tabular}

Source: primary data.

The above table shows that 27 per cent of respondents belong to the Airtel followed by 25 per cent belong to Vodafone, 14 per cent belong to BSNL, 12 per cent of the respondents belong to Idea cellular 9 per cent from Reliance and remaining 4 per cent of the respondents are from other operators.

Table: 8 Distribution of Sample Respondents of Motivational Factors of MNPs

\begin{tabular}{|l|c|c|}
\hline \multicolumn{1}{|c|}{ Particulars } & No. of Respondents & Percentage \\
\hline Good Coverage & 19 & 21.35 \\
\hline Low Tariff & 13 & 14.61 \\
\hline Voice quality & 11 & 12.36 \\
\hline Free Talk time \& SMS packs & 17 & 19.10 \\
\hline Free Internet & 4 & 4.49 \\
\hline Value Add Services & 3 & 3.37 \\
\hline Brand Loyality & 6 & 6.74 \\
\hline Roaming & 2 & 2.25 \\
\hline Convenience & 7 & 7.87 \\
\hline 3G Technology & 3 & 3.37 \\
\hline Other & 4 & 4.49 \\
\hline Total & $\mathbf{8 9}$ & $\mathbf{1 0 0 . 0 0}$ \\
\hline
\end{tabular}

Source: Primary data.

The above table shows that MNP influence (motivation) factors to choose operators. Twenty one per cent of the respondents are motivated by good coverage factor followed by 19 per cent motivated by free talk time, free SMS packs 14 per cent motivated by low tariff, 12 per cent motivated by voice quality, 07 per cent 
motivated by convenience, 6 per cent of the respondents motivated by brand loyalty. The service providers to extent maximum level of service will have to put up more effort to provide better service to retain the customers.

$\mathbf{H}_{\mathbf{0}}$ : There is no significant relationship between Gender of the sample respondent and their willingness to change current mobile service provider

Table 9

\begin{tabular}{|c|c|c|c|c|c|c|c|c|c|c|}
\hline \multirow{3}{*}{ Gender } & \multicolumn{10}{|c|}{ Willingness to change current mobile service provider } \\
\hline & \multicolumn{2}{|c|}{ Strongly Disagree } & \multicolumn{2}{|c|}{ Disagree } & \multicolumn{2}{|c|}{ Agree } & \multicolumn{2}{|c|}{ Strong agree } & \multicolumn{2}{|c|}{ Total } \\
\hline & $\mathbf{F}$ & $\%$ & $\mathbf{F}$ & $\%$ & $\mathbf{F}$ & $\%$ & $\mathbf{F}$ & $\%$ & $\mathbf{F}$ & $\%$ \\
\hline Male & 98 & 83.8 & 37 & 78.7 & 32 & 62.7 & 18 & 40.9 & 185 & 71.4 \\
\hline Female & 19 & 16.2 & 10 & 21.3 & 19 & 37.3 & 26 & 59.1 & 74 & 28.6 \\
\hline Total & 117 & 100 & 47 & 100 & 51 & 100 & 44 & 100 & 259 & 100 \\
\hline Chi-Square & $\chi 2=31$ & $=0.000$ & $\mathrm{If}=3$ & 1 & & & & & & \\
\hline
\end{tabular}

**significant at 0.01 level; TV - Table Value

F: frequency of sample respondents; \% -percentage

The table 9 shows gender of the sample respondents and there willingness to change current mobile service provider. It is found that statistically significant at 0.01 per cent level and table value 11.345 . It is also found that there is a relation between gender of the respondent and willingness to change current operator. Hence the hypothesis is accepted.

$\mathbf{H}_{\mathbf{O}}$ : There is no significant difference between the income of the subscriber and user satisfaction of current service provider.

Table 10

\begin{tabular}{|c|c|c|c|c|c|c|c|c|c|c|c|c|}
\hline \multirow{2}{*}{ onthly Income } & \multicolumn{2}{|c|}{ Highly Satisfied } & \multicolumn{2}{|c|}{ Satisfied } & \multicolumn{2}{|c|}{ Neutral } & \multicolumn{2}{|c|}{ Dissatisfied } & \multicolumn{2}{|c|}{ Highly dissatisfied } & \multicolumn{2}{|c|}{ Grand Total } \\
\hline & $\mathbf{F}$ & $\%$ & $\mathbf{F}$ & $\%$ & $\mathbf{F}$ & $\%$ & $\mathbf{F}$ & $\%$ & $\mathbf{F}$ & $\%$ & $\mathbf{F}$ & $\%$ \\
\hline Below 10000 & 9 & 18.0 & 8 & 14.3 & 10 & 11.4 & 6 & 17.1 & 5 & 16.7 & 38 & 14.7 \\
\hline $10001-20000$ & 19 & 38.0 & 20 & 35.7 & 17 & 19.3 & 14 & 40.0 & 11 & 36.7 & 81 & 31.3 \\
\hline $20001-30000$ & 12 & 24.0 & 17 & 30.4 & 26 & 29.5 & 8 & 22.9 & 4 & 13.3 & 67 & 25.9 \\
\hline Above 30001 & 10 & 20.0 & 11 & 19.6 & 35 & 39.8 & 7 & 20.0 & 10 & 33.3 & 73 & 28.2 \\
\hline Total & 50 & 100 & 56 & 100 & 88 & 100 & 35 & 100 & 30 & 100 & 259 & 100 \\
\hline Chi-Square & $\chi^{2}=$ & (a) $;(\mathrm{p}=$ & $6)^{(a)}$ & $f=12$ & $\mathrm{TV}=$ & 21.03 & & & & & & \\
\hline
\end{tabular}

(a) - Not significant;

Source: Primary data.

The above table shows income of sample respondents and their satisfaction level towards the current operator, it is found that statistically not significant. It is also found that there is no relation between income of the sample respondents and satisfaction level of current operator. Hence the hypothesis is rejected.

\section{Findings}

As per the above data and interpretation most of the respondents were men between 20-30 years having monthly income less than 20,000. Around $96 \%$ of the respondent were use prepaid service connection and more than 27 per cent of mobile subscribes opted for Airtel as the service provider. It was followed by 25 per cent opted for Vodafone. Rest of respondent were using some other service provider. Most of the respondents are aware of MNP through advertising. The consent level of the respondents towards the switch over the MNP, around 45 per cent of respondent agree to switch over the present operators. 44 per cent of the respondents were satisfied with current operators and 48 per cent of respondent had not opted even once for MNP around 68 per cent respondent dissatisfied with current operator due to coverage, connectivity, tariff problem and 34 per cent of the respondent already switch over to other service provider among these respondents around 68 per cent of the respondents opted MNP due to coverage, high tariff, lack of voice quality and less value added service with current operators. So they are dissatisfied with current operator. Hence the service provider most extent quality service connectivity at affordable cost to retain their loyal consumer. Operators wise Idea cellular emerged as the consistent gainer in the MNP race. With Airtel and Vodafone India vying for the second spot. As in July 2014. Idea registered a net gain of 9.14 million subscriber on its network through MNP. 


\section{Suggestion}

Every company is trying to keep eye on others customers and trying to retain their own users. MNP has directly affected the industries to a greater extent than subscribers, which suggests implications for both regulators and industries as well.

> Mobile number portability scheme, the ultimate hero is the customer. Now, he can change his service provider without any worries. This is a strong weapon in the hands of the users. So, operators should satisfied to the subscriber with quality of service.

$>$ Operators should satisfy the customer and focus on maximum the relevance of offers based on a subscriber's profile, prepaid balance, real time requirements, past behavior.

$>$ Operators should set up a customer care cell to seek feedback from subscribers opting for change.

$>$ The strategy for attracting new ones should consider the consumer expectation and mode operator's service to provide the desired propositions.

$>$ Operator should provide secure affordable and high quality service to all users.

> Operator should provide one nation full mobile number portability and work towards one nation free roaming.

$>$ In case of any call drop, operator has to send an SMS to subscriber for getting money back.

> In case subscriber makes a call to customer care, it should be answer quickly and without any charges but now so many operators collects charges from customer. It makes the consumer unhappy it pushes the customer to switch over to another operator.

> Subscriber makes a call to operator for switching but the current operator is asking much information about the customer. This enquiry confuses the customer and avoids the switching. This is a strategy of operator. As per TRAI, changing operator is right of customer so present operator shall not make delay of switching activities.

> The companies must understand that if they are targeting are their competitors customers, same are is targeting their customer as well. It is a open secret. So the operator aim should be to improve upon service quality for the users.

$>$ Are more important factory is value. It has been proven to be a main reason why subscriber study with mobile service providers. So, operators should maintain values to retain their customer.

> Present, the MNP facility is restricted to the local service area. In order to port outside the local circle, a user has to either get a new number or pay additional roaming changes. It suggested the implement of MNP national wide and award the extra charges.

\section{References}

[1]. K.Kumaresh and S.Praveena (2011) an empirical analysis of consumer switching behavior towards mobile number portability, National monthly referred journal of research in commerce \& management. Vol.No.1, issue no.11, pp.10-22.

[2]. Nishat Anjum (2012) Mobile number portability solution implementation, international journal of electronic \& Communication technology, IJECT, Vol.3, Issue 1, Jan.-March 2012, pp.125-128.

[3]. Partiksinh Sureshsinh Vaghela (2012), Customer Preference for Mobile Number Portability, International Journal of Management and Social Sciences Research (IJMSSR), Vol.1, pp.71-75.

[4]. Sutherland, E. (2009). Counting customer, subscribers and mobile phone numbers. Inf, 11(2), 6-23.

[5]. B.K.Suthar, (2012), A study on consumer behavior after mobile number portability with reference to Gujarat telecom circle. EISSN 2277-4955, Vol.3, No.2, May-Aug-2012, pp.1-7.

[6]. Solomon Adeyemi Odunaike (2010) The impact of mobile number portability on TUT students on-line connectivity ISECON proceedings, v27 n1348.

[7]. Gaya Prasad Patel, Effect of MNP on customer relation in Madhya Pradesh Circle of BSNL a state owned Telecommunication Company, published by BSNL, Bhopal, India.

[8]. http://trak.in/tags/business/2011/08/09/India-mobile-telecom-subscriber-growth-june-2011

[9]. http://www.trai.gov.in/WriteReadData/trai/upload/PressReleases/835/Press\%20Release\%20June14.pdf. 